\title{
Exploring the Cointegration Relation among Top Eight Asian Stock Markets
}

\author{
Muhammad Rizwanullah1, Lizhi Liang1 ${ }^{*}$, Xiuyuan Yu1, Jinan Zhou1, Muhammad Nasrullah², \\ Muhammad Uzair Ali ${ }^{3}$ \\ ${ }^{1}$ Collage of Public Administration, Xiangtan University, Xiangtan, China \\ ${ }^{2}$ College of Agricultural Economics and Management, Northeast Agricultural University, Harbin, China \\ ${ }^{3}$ Collage of Business, Xiangtan University, Xiangtan, China \\ Email: *188793258@qq.com
}

How to cite this paper: Rizwanullah, M., Liang, L. Z., Yu, X. Y., Zhou, J. N., Nasrullah, M., \& Ali, M. U. (2020). Exploring the Cointegration Relation among Top Eight Asian Stock Markets. Open Journal of Business and Management, 8, 1076-1088. https://doi.org/10.4236/ojbm.2020.83068

Received: March 7, 2020

Accepted: April 18, 2020

Published: April 21, 2020

Copyright (c) 2020 by author(s) and Scientific Research Publishing Inc. This work is licensed under the Creative Commons Attribution International License (CC BY 4.0).

http://creativecommons.org/licenses/by/4.0/

\begin{abstract}
Asian stock market faces many favorable and unfavorable incidents of collapsing internal market in last decades. The local investors are interested especially in the countries like China, Malaysia, UAE and Bangladesh which are politically, geographically and strategically important as investment portfolio point of view. The investors have experience of moving many markets together in long run which is a bad news for investors to diversify their investment in different markets. Therefore, the objectives of the study is to find the direction and short and long run association among top eight Asian stock Markets by applying Johansen cointegration test and Granger Causality Test. The augmented unit root test and Phillips-Peron proved the presence of unit root in data at level. The cointegration analysis test based on trace statistics shows five cointegrating equation, while the maximum eigen valve test indicates two cointegrating equation at 5 percent significant level. Results imply that these markets are strongly cointegrated in long term which can diversify local and foreigner investors. The Granger Causality shows that 13 pairs of markets are bidirectional while 12 pairs are unidirectional and 3 pairs have no causality. From the result it is obtained that integrated markets are useful for decreasing the chances of financial stability and asymmetric shocks, which can strengthen the capability of the economy to absorb the shocks and adequate the risk of international financial contagion. It is concluded that for investor views there are still possibilities for efficient portfolio diversification across these markets. In addition further study should be carried out to find the reason of cointegration.
\end{abstract}

\section{Keywords}

Cointegration, Eigenvalue, Portfolio, Granger Causality 


\section{Introduction}

Studies of financial market integration are motivated during the last two decades, due to many countries in the world undertaken the measure of increasing liberalization. This liberalization of stock markets can be in form of removal of ownership barriers, exchange controls or capital barriers (Ragunathan, 1999). In 1970 government restricted the flow of international capital in major countries. In addition, it has been noted that during 1980, when the barriers to international capital mobility were eliminated, it provides easy way to access one country's capital market and thus lead to integration in financial market (Throop, 1994).

Various studies are carried out to find the level of integration by using new technique among various stock markets (Narayan et al., 2015). Due to one of the fastest growing research area, stock market cointegration provides a strong link to reduce the risk from a holding portfolio, fundamental tenant of investment strategy and a relevant implication for the investors, who hold a diversified portfolio in international security (Wuthisatian, 2014). Financial integration exists among various stock markets in the world can repel the international investors in order to minimize the potential risk of their each and every investment. Indices of different countries stock market are not following the same trend or not integrated; then such market attract international investor to diversify their portfolio investment among these countries. International investors are mostly interested in emerging markets, but the interdependency among these stock markets and developed stock markets affect the diversification (Pretorious, 2002). Convergence of stock markets is possible due to sharing of short-term and long-term relationship existing among different countries stocks markets which means the markets indices are integrated (Narayan et al., 2011). For making policy, regional integration play an important role in expanding the base for investors and also broaden the range of financial product, which is helpful for strengthening domestic capital market to compete global market. An integrated markets are useful for decreasing the chances of financial stability and asymmetric shocks, which can strengthen the capability of the economy to absorb the shocks and adequate the risk of international financial contagion (Umutlu et al., 2010; Beine et al., 2010; Narayan et al., 2011).

Interest of researchers increases due to presence of correlation among global markets. Benefits gained by researchers from global market integration are documented and categorized the study into; relationship existing among developed and emerging stock market (Benzion et al., 1996), relationship between stock prices and international macroeconomics variable (Dimitrova, 2005) and interdependency of neighborhood market (Ali et al., 2011). Among other benefits, raising the allocation of capital globally and reducing share risk of countries by decreasing consumption volatility, increase in investment opportunity and increasing the growth rate (Daly, 2003).

Based on the previous literature, the research is carried out to explore the long 
run relation among top 8 Asian market indices and to find out the causal relation among top 8 Asian markets.

\section{Literature}

Many researches are carried out in last two decades to find the possible cointegration among international stock markets. However, the results are incompatible and showing no consent on the result of cointegration even in between major international stock markets.

Largest Europe stock markets are examined from 1975-1991 by Corhay et al., (1993) and got the evidences of cointegration existing among France, Germany, Italy, Netherland and UK. Similar results are obtained by Chen et al., (2002), by using the six major stock markets indices of Latin America. Kasa (1992) strongly reject the hypothesis of no cintegration by using monthly and quarterly data from 1974-1990 of five major stock market of Canada, Germany, England, Japan and USA. A solid evidence of one cointegrating vector is founded for these stock markets and his conclusion is not similar with previous work in this area, which implies low or no cointegration among stock markets. Richards (1995) criticize the study work of Kasa (1992) and investigate cointegration by using both Johansen test and Engle Granger methodology from 1964-1994 between 16 national equity market and world equity index. The study reject null hypothesis of no cointegration, as a result the author concludes that in long run the foreign and domestic equity markets will move significantly differently, highlighting the reason of investment in abroad to reduces the risk. Kanas (1998), analyses daily data from 1983 to 1986 to find the pairwise cointegration between US and six European major stock markets. Ahlgren and Antell (2002) carried out study by using data from time period 1980-1997 to find cointegration. The study concluded the evidence for cointegration is week in between Germany, France, Finland, US, UK and Sweden. Choudhry (1997) investigates the evidence of long-run relationship exit among their nominated markets. Wong et al. (2005) find out the short- and long-term relationship between India, United States, Japan and United Kingdom. The results concluded that India is cointegrated with these mature markets and is sensitive in the long run to the dynamics change in these markets.

By moving one step further on the concept of cointegration, some authors also studied cointegration of various stock markets during the period of crises and period of pre crises. Sheng and $\mathrm{Tu}$ (2000) took interest to investigate different degrees of relationship amongst the North-East Asian and South-East Asian countries during and before the Asian financial crisis which started in 1997. Their study reviled the evidence of no cointegrational relationship exist among the five North-East country indices during and before crises period while there is at least one cointegrational relationship exist during and pre crises period of the

five South-East Asian country indices. Similar study was conducted by Fan (2003) to find out the cointegration of Taiwan in China, Thailand, Singapore, 
Hong Kong in China, Japan and United State during and before the Asian crises and find out no evidence of cointegrational relationship before crisis, but after the crisis a cointegrational relationship was founded in Asia-Pacific indices.

During examining the study of cointegration test among international indices, many researchers also examined the causality of these indices. Sheng and Tu (2000) suggested that during the period of financial crisis, US market still causes some Asian markets (South Korea and Hong Kong in China) which reflect the dominant role on Asian market indices. Wong et al. (2005) find out that the Indian market is sensitive to dynamics changes in Japan, UK and US markets. In the study there is no causality from India market to any developed markets but in short run both Japan and US Granger cause the Indian stock market. Fan (2003) reveals that sudden changes in United State market have an intensive effect on the Asia-Pacific markets. Japan can only affect Thailand but none of other market Taiwan in China, Singapore and Hong Kong in China in the study.

\section{Data}

To provide updated and robust results, the study uses top eight Asian stock markets ranked on the basis of their market capitalization shown in Table 1 and key indicators of selected exchanges shown in Table 2. Research study uses daily price index of last eighteen years spanning from 01 January 2000 to 29 December 2017 and analyzed in local units obtained from yahoofinance.com. Following stock returns that are used in study are $\wedge$ N225 (Japan), ^SSEC (Shanghai in China), 0388.HK (Hong Kong in China), ^BSESN (Bombay), ^KS11 (Korea), $\wedge$ TWII (Taiwan in China), S68.SI (Singapore) and $\wedge$ JKSE (Indonesia). During analysis the study faces the problem of missing observation due to difference in stock market holidays which are adjusted through filling the data of adjusted day, following the study of Hirayama and Tsutsui (1998) and Majid et al. (2008). Based on the previous studies Kasa (1992) and Richards (1995) all index values are transferred into log form in order to get absolute changes instead of relative changes. The study also plotted time series of 8 indices shown in Figure 1.

Table 1. History of selected stock markets at the end of 2016.

\begin{tabular}{ccccc}
\hline Region/Country & Stock exchange & $\begin{array}{c}\text { Market } \\
\text { capitalization, } \\
\text { billion USD }\end{array}$ & $\begin{array}{c}\text { Number of } \\
\text { listed } \\
\text { companies }\end{array}$ & $\begin{array}{c}\text { Trading volume, } \\
\text { billion USD }\end{array}$ \\
\hline Japan & Tokyo SE & 4955 & 3541 & 5626 \\
China & Shanghai SE & 4100 & 1182 & 7510 \\
Hong Kong in China & Hong Kong SE & 3193 & 1973 & 1350 \\
India & Bombay SE & 1567 & 5821 & 113 \\
South Korea & KOSPI CI & 1255 & 2059 & 1665 \\
Taiwan in China & Taiwan SE & 844 & 911 & 512 \\
Singapore & Singapore exchange & 640 & 757 & 197 \\
Indonesia & Indonesi SE & 426 & 537 & 92 \\
\hline
\end{tabular}

Source: OECD Equity Markets Review 2017. 

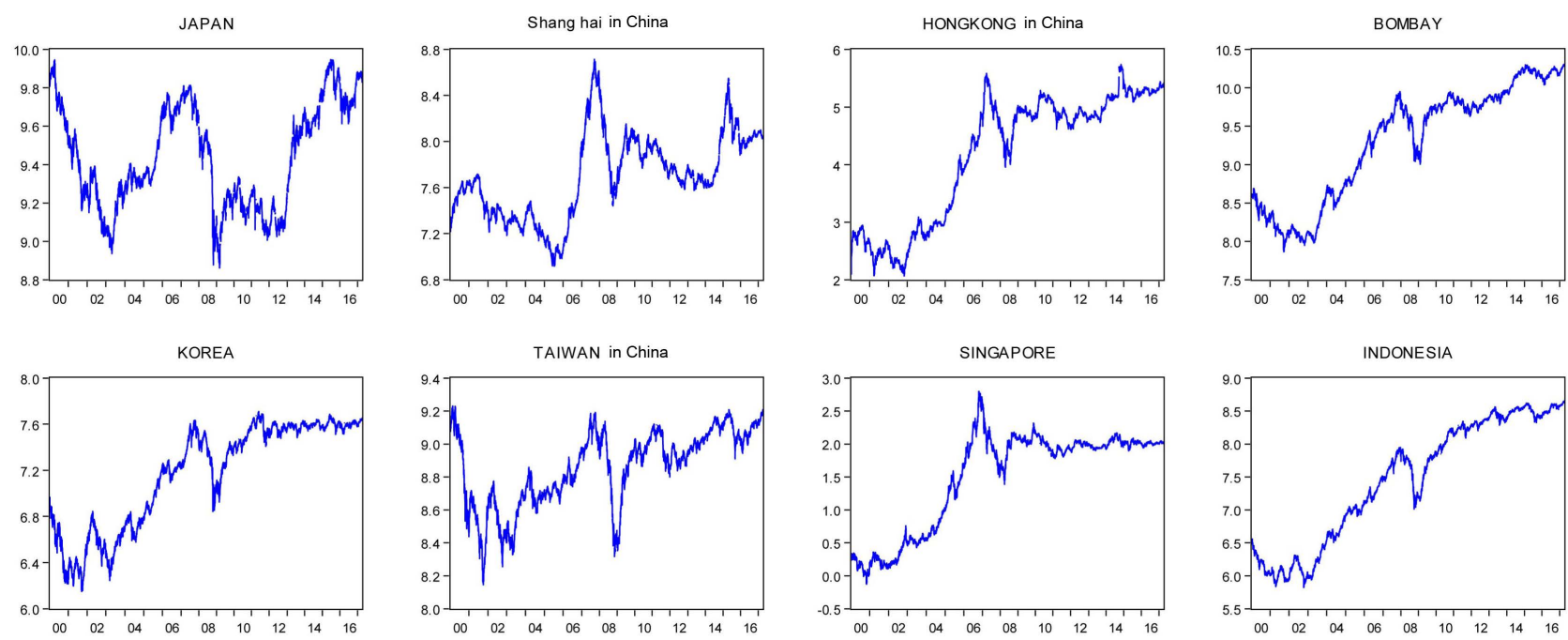

Figure 1. Daily stock price index of 8 regions or countries, January 2000-December 2017.

Table 2. Key indicators of selected stock exchange, as of end 2016.

\begin{tabular}{|c|c|c|c|c|}
\hline $\begin{array}{l}\text { Region/ } \\
\text { Country }\end{array}$ & Stock Exchanges & $\begin{array}{c}\text { Market } \\
\text { capitalization/GDP }\end{array}$ & $\begin{array}{c}\text { Total value } \\
\text { traded/GDP Turnover }\end{array}$ & Turnover \\
\hline Japan & Tokyo SE & 1.12 & 1.27 & 1.14 \\
\hline China & $\begin{array}{l}\text { Shanghai SE and } \\
\text { Shenzhen SE }\end{array}$ & 0.64 & 1.68 & 2.61 \\
\hline Hong Kong in China & $\begin{array}{l}\text { Stock Exchange } \\
\text { of Hong Kong }\end{array}$ & 9.90 & 4.19 & 0.42 \\
\hline India & National SE & 0.67 & 0.30 & 0.45 \\
\hline South Korea & Korea Exchange & 0.95 & 1.26 & 1.33 \\
\hline Taiwan in China & $\begin{array}{l}\text { Taiwan SE and } \\
\text { Taipei Exchange }\end{array}$ & 1.82 & 1.01 & 0.55 \\
\hline Singapore & Singapore Exchange & 2.17 & 0.67 & 0.31 \\
\hline Indonesia & Indonesia SE & 0.45 & 0.10 & 0.22 \\
\hline
\end{tabular}

Source: OECD Equity Markets Review 2017.

\section{Methodology}

It is important to check the data before analyzing data for various problems (Nasrullah et al., 2019; Saddozai et al., 2015). Long run equilibrium relationship between non-stationary variable existing in time series data is one of the important issues for economists. To capture this relationship, Engle and Granger (1987) introduce a concept of cointegration. Stock (1987) investigate that if two variables of series data have unit root and cointegrated with each other then there estimation of parameters is highly efficient and if they have the same trend, then they have a long run relationship. Cointegration test is important to find the nature and trend in time series variable.

Dickey Fuller $(1979,1981)$ developed a procedure to check the stationarity of time series variable before empirical analysis. A series $X_{t}$ is supposed to be coin- 
tegrated of order " $b$ " if they have stochastic ARMA and stationarity at differencing " $b$ " times which is represented as: $X_{t}=I(b)$. Mostly, non-stationary time series variable are co-integrated of order $I(1)$, if data set are stationary at level and integrated also then it is denoted by $I(0)$. Suppose if two variables $A_{t}$ and $B_{b}$ are integrated at order $I(0)$, then regression equation $\left(A_{t}=\alpha_{o}+\alpha_{1} B_{t}+e_{t}\right)$ is applied to estimate the long term relationship between these variables and stationarity of residuals will be estimated through stationarity test. If the estimated results of the variables are not cointegrated at level $(I(0))$ then at order $I(1)$ the estimated residuals will be integrated. Furthermore, the results of regression in case of non-stationary series will be misleading, spurious in such conditions.

$$
A_{t}=\alpha_{o}+\alpha_{1} B_{t}+e_{t}
$$

$e_{t}$ presents estimated residuals of data variables which is important for checking stationarity by applying common tests of stationarity that is Phillips-Perron (PP) and Augmented Dickey-Fuller (ADF).

Possibilities of having more than one integrating vector will occur if there are more than two variables in the model which implies that variables are forming numerous equilibrium relationship, which generate a joint evolution for all variable. Usually, for $n$ numbers of variable has $n-1$ cointegrating vector but if $n$ $=7$, then a simple single equation approach is not enough to resolve this serious problem. So, an alternate approach is required and thus Johansen and Julius (1990) developed a multiple equations approach. The Johansen method of cointegration has unique characteristics that it can measure the second order series data which other approaches cannot estimate like ARDL.

Simple error correction model is extended to a multivariate equation. Supposing that there are six variables $T_{t}, U_{t}, V_{t}, W_{t}, X_{t}$ and $Z_{t}$ then we have using (matrix notation for $A_{t}=\left[T_{t}, U_{t}, V_{t}, W_{t}, X_{t}, Z_{t}\right]$ )

$$
A_{t}=\alpha_{1} A_{t-1}+\alpha_{2} A_{t-2}+\cdots+\alpha_{k} A_{t-k}+u_{t}
$$

Equation (2) is similar to simple Equation (1) having only variables of $A_{t}$ and $B_{t}$. Reformulate Equation (2) in a vector error correction model (VECM) is below:

$$
\Delta A_{t}=\Gamma_{1} \Delta A_{t-1}+\Gamma_{2} \Delta A_{t-2}+\cdots+\Gamma_{k} \Delta A_{t-k-1}-\Pi A_{t-1}+u_{t}
$$

where

$$
\begin{gathered}
\Gamma_{1}=\left(I-\alpha_{1}-\alpha_{2}-\cdots-\alpha_{k}\right) \quad(i=1,2, \cdots, k-1) \\
\Pi=-\left(I-\alpha_{1}-\alpha_{2}-\cdots-\alpha_{k}\right)
\end{gathered}
$$

Residual $u_{t}^{\prime}$ s are supposed to be independent and distributed identically as a multi-normal distribution having $\delta$ variance and zero mean. Suppose there are six variables in $A_{t}=\left[T_{t}, U_{t}, V_{t}, W_{t}, X_{t}, Z\right]$, require to check $6 \times 6 \Pi$ matrix. The information about long run equilibrium relationship contains in $\Pi$ matrix shown in Equation (3). This long run information of matrix (П) are decomposed into $\Pi=\gamma \beta$ where $\gamma$ contain the adjustment of speed to attain the level of long-run equilibrium while the coefficient of long-run matrix is $\beta$. Thus, in case 
of two variables model $\gamma A_{t-1}$ term is equal to error correction term $\left(A_{t-1}-\gamma-\right.$ $\left.\gamma_{1} B_{t-1}\right)$, by accepting the facts that $\gamma A_{t-1}$ having up to $(n-1)$ vectors in a multivariate structure. For simplifying the reason, it is considered that there are only two lags $(k=2)$, model are as follow:

$$
\left(\begin{array}{c}
\Delta X_{t} \\
\Delta U_{t} \\
\Delta V_{t} \\
\Delta W_{t} \\
\Delta X_{t} \\
\Delta Z_{t}
\end{array}\right)=\Gamma_{1}\left(\begin{array}{c}
\Delta X_{t-1} \\
\Delta U_{t-1} \\
\Delta V_{t-1} \\
\Delta W_{t-1} \\
\Delta X_{t-1} \\
\Delta Z_{t-1}
\end{array}\right)+\Pi\left(\begin{array}{l}
X_{t-1} \\
U_{t-1} \\
V_{t-1} \\
W_{t-1} \\
X_{t-1} \\
Z_{t-1}
\end{array}\right)+e_{t}
$$

Equation (4) can be written as follow:

$$
\left(\begin{array}{l}
\Delta X_{t} \\
\Delta U_{t} \\
\Delta V_{t} \\
\Delta W_{t} \\
\Delta X_{t} \\
\Delta Z_{t}
\end{array}\right)=\Gamma_{1}\left(\begin{array}{c}
\Delta X_{t-1} \\
\Delta U_{t-1} \\
\Delta V_{t-1} \\
\Delta W_{t-1} \\
\Delta X_{t-1} \\
\Delta Z_{t-1}
\end{array}\right)+\left(\begin{array}{ll}
\alpha_{11} & \alpha_{12} \\
\alpha_{21} & \alpha_{22} \\
\alpha_{31} & \alpha_{32} \\
\alpha_{41} & \alpha_{42} \\
\alpha_{51} & \alpha_{52} \\
\alpha_{61} & \alpha_{62}
\end{array}\right)\left(\begin{array}{llllll}
\beta_{11} & \beta_{21} & \beta_{31} & \beta_{41} & \beta_{51} & \beta_{61} \\
\beta_{12} & \beta_{22} & \beta_{32} & \beta_{42} & \beta_{52} & \beta_{62}
\end{array}\right)\left(\begin{array}{l}
X_{t-1} \\
U_{t-1} \\
V_{t-1} \\
W_{t-1} \\
X_{t-1} \\
Z_{t-1}
\end{array}\right)+e_{t}
$$

Error correction (i.e. for $\Delta X_{t}$ on lift hand side) in Equation (5) can be investigated as in following equation:

$$
\Pi Z_{t-1}=\left(\left[\begin{array}{c}
\alpha_{11} \\
\beta_{11} \\
+ \\
\alpha_{12} \\
\beta_{12}
\end{array}\right]\left[\begin{array}{c}
\alpha_{11} \\
\beta_{21} \\
+ \\
\alpha_{12} \\
\beta_{22}
\end{array}\right]\left[\begin{array}{c}
\alpha_{11} \\
\beta_{31} \\
+ \\
\alpha_{12} \\
\beta_{32}
\end{array}\right]\left[\begin{array}{c}
\alpha_{11} \\
\beta_{41} \\
+ \\
\alpha_{12} \\
\beta_{42}
\end{array}\right]\left[\begin{array}{c}
\alpha_{11} \\
\beta_{51} \\
+ \\
\alpha_{12} \\
\beta_{52}
\end{array}\right]\left[\begin{array}{c}
\alpha_{11} \\
\beta_{61} \\
+ \\
\alpha_{12} \\
\beta_{62}
\end{array}\right]\right)\left(\begin{array}{c}
X_{t-1} \\
U_{t-1} \\
V_{t-1} \\
W_{t-1} \\
X_{t-1} \\
Z_{t-1}
\end{array}\right)
$$

$\Pi_{1}$ shows the first row of the $\Pi$ matrix. Simplified form of Equation 6 as follows:

$$
\begin{aligned}
\Pi Z_{t-1}= & \alpha_{11}\left(\beta_{11} X_{t-1}+\beta_{21} U_{t-1}+\beta_{31} V_{t-1}+\beta_{41} W_{t-1}+\beta_{51} Y_{t-1}+\beta_{61} Z_{t-1}\right) \\
& +\alpha_{12}\left(\beta_{12} X_{t-1}+\beta_{22} U_{t-1}+\beta_{32} V_{t-1}+\beta_{42} W_{t-1}+\beta_{52} Y_{t-1}+\beta_{62} Z_{t-1}\right)
\end{aligned}
$$

The cointegrating vectors with $\alpha_{11}$ and $\alpha_{12}$ terms of their respective speed of adjustment are clearly shown in Equation (7).

Johansen (1988) developed a reduced rank regression procedure through which the rank of $\Pi$ matrix can be tested. In order to determine the number of cointegration equations, Johansen and Julius (1990) explained two ways of estimation $\Pi$ matrix. Maximum eigenvalue denoted by $\lambda_{\max }$ is the first method proposed by Johansen in which largest eigenvalue is ordered in descending by considering either they are significantly different from zero. The following statistics are used to find the number of characteristics roots that are significantly different from zero:

$$
\lambda_{\max }(r r+1)=-T \ln (1-\lambda r+1)
$$


Second method of johenson is known as trace test which is based on likelihood ratio test about the trace of the matrix. The aim of this test is to focus either the trace is increases by adding more eigenvalue beyond the $t$ th eigenvalue. The test statistic will be:

$$
\lambda_{\text {trace }}(r)=-T \sum t=r+\ln (1-\lambda r+1)
$$

Johansen and Julius (1990) provide critical values for both statistics. Bivariate VAR model is used to find out the granger causality relationship if long run relationship exists among stock price index variables. For investigating further pairwise granger causality among two variables $(A$ and $B$ ) bivariate regression model is used to find $A$ causes $B$ and $B$ causes $A$

$$
\begin{aligned}
& B_{t}=\alpha_{0}+\alpha_{1} B_{i-1}+\cdots+\alpha_{n} B_{i-k}+\beta_{1} A_{i-1}+\cdots+\beta_{n} A_{i-k}+\varepsilon_{t} \\
& A_{t}=\alpha_{0}+\alpha_{1} A_{i-1}+\cdots+\alpha_{m} A_{i-1}+\beta_{1} B_{i-k}+\cdots+\beta_{m} B_{i-k}+u_{t}
\end{aligned}
$$

Acceptation or rejection of hypothesis is based on the calculated F-statistics. Model 10 is used for testing hypothesis of " $A$ does not granger cause $B$ " and Equation (11) is used for hypothesis that " $B$ does not granger cause $A$ ".

\section{Empirical Findings}

\subsection{Tests of the Unit Roots}

Before starting cointegration, checking the problem of stationarity of a given data series is important. The study uses Phillips-Peron (PP) and Augmented Dickey-Fuller (ADF) (PP) unit root for stationarity based on model with constant and trend. Number of lag selection is based on the minimum Akaike Information criterion (AIC). ADF and PP results show that all data variables accept the hypothesis of unit root at level, which means that data are not stationary except Korea and Taiwan in China which is significant at 10 percent level. In order to make it stationary, same test are used at first difference of stock market variables and resulted that at first difference all variables become stationary. This result shows that all variable indices are integrated at same order $I(1)$. Presence of unit root suggesting the evidence of weak efficiency form of selected Asian

\begin{tabular}{|c|c|c|c|c|}
\hline \multirow{2}{*}{ Market indices } & \multicolumn{2}{|c|}{$\mathrm{ADF}$} & \multicolumn{2}{|c|}{$\mathrm{PP}$} \\
\hline & Level & 1st Difference & Level & 1st difference \\
\hline Japan & -2.28 & $-68.79^{* * *}$ & -2.17 & $-68.99^{* * *}$ \\
\hline Shanghai in China & -1.78 & $-64.48^{* * *}$ & -1.83 & $-64.49^{* * *}$ \\
\hline Hong Kong in China & -1.53 & $-62.02^{* * *}$ & -1.78 & $-62.21^{\star * *}$ \\
\hline Bombay & -2.30 & $-47.13^{* * *}$ & -2.30 & $-61.69^{* * *}$ \\
\hline Korea & $-3.13^{*}$ & $-65.08^{\star * *}$ & -3.04 & $-65.24^{* * *}$ \\
\hline Taiwan in China & $-3.36^{*}$ & $-63.80^{* * *}$ & $-3.41^{\star *}$ & $-63.80^{* * *}$ \\
\hline Singapore & -1.14 & $-63.21^{\star * *}$ & -1.17 & $-63.16^{* * *}$ \\
\hline Indonesia & -2.44 & $-59.86^{\star * *}$ & -2.47 & $-59.77^{\star * *}$ \\
\hline
\end{tabular}
markets (Mcmiken, 2014; Nasrullah et al., 2020). Results are shown in Table 3.

Table 3. Unit root test.

Note: ${ }^{*}{ }^{* *},{ }^{* *}$ denotes at $10,5,1$ percent significance level. 


\subsection{Johenson Cointegration Test}

Proper lag selection is important for applying the Johenson and Julius cointegration test. Proper lag should be selected where the AIC value is less. Minimum value of AIC is founded on lag 7 which is used during analysis. Cointegration has been checked through critical trace statistics and maximum Eigen value. The result of trace statistics implies that there are 5 series of cointegrating vector at 5\% confidence interval. Similarly, maximum Eigen value implies that there are 2 number of cointegration equation, which implies that these all markets can easily diversify foreign investment (Pretorious, 2002). Null hypothesis of no cointegration is not accepted. Result shows a long term relationship among all top 8 Asian stock market which are shown in Table 4 and Table 5 .

Table 4. Cointegration test of top 8 Asian indices (trace).

\begin{tabular}{ccccc}
\hline $\begin{array}{c}\text { No. Cointegration } \\
\text { Equation (s) }\end{array}$ & $\begin{array}{c}\text { Eigen } \\
\text { value }\end{array}$ & $\begin{array}{c}\text { Trace } \\
\text { statistics }\end{array}$ & $\begin{array}{c}\text { Critical value } \\
(0.05)\end{array}$ & Probability $^{* *}$ \\
\hline $0^{*}$ & 0.014225 & 241.9711 & 159.5297 & 0.0000 \\
$1^{*}$ & 0.012606 & 179.9079 & 125.6154 & 0.0000 \\
$2^{*}$ & 0.009070 & 124.9534 & 95.75366 & 0.0001 \\
$3^{*}$ & 0.007827 & 85.48172 & 69.81889 & 0.0017 \\
$4^{*}$ & 0.006487 & 51.44157 & 47.85613 & 0.0222 \\
5 & 0.002623 & 23.24770 & 29.79707 & 0.2341 \\
6 & 0.002037 & 11.87047 & 15.49471 & 0.1633 \\
7 & 0.000701 & 3.037789 & 3.841466 & 0.0813 \\
\hline
\end{tabular}

Note: MacKinnon Haug Michelis et al. (1999) p-values.

Table 5. Cointegration test of top 8 Asian indices (Maximum Eigenvalue).

\begin{tabular}{ccccc}
\hline $\begin{array}{c}\text { No. Cointegration } \\
\text { Equation }(\mathrm{s})\end{array}$ & Eigen value & $\begin{array}{c}\text { Max-eigen } \\
\text { Statistics }\end{array}$ & $\begin{array}{c}\text { Critical value } \\
(0.05)\end{array}$ & $\begin{array}{c}\text { Probability } \\
{ }^{* *}\end{array}$ \\
\hline $0^{*}$ & 0.014225 & 62.06321 & 52.36261 & 0.0038 \\
$1^{*}$ & 0.012606 & 54.95450 & 46.23142 & 0.0046 \\
$2^{*}$ & 0.009070 & 39.47164 & 40.07757 & 0.0584 \\
$3^{*}$ & 0.007827 & 34.04015 & 33.87687 & 0.0478 \\
$4^{*}$ & 0.006487 & 28.19387 & 27.58434 & 0.0418 \\
5 & 0.002623 & 11.37723 & 21.13162 & 0.6097 \\
6 & 0.002037 & 8.832678 & 14.26460 & 0.3003 \\
7 & 0.000701 & 3.037789 & 3.841466 & 0.0813 \\
\hline
\end{tabular}

Note: MacKinnon Haug Michelis et al. (1999) p-values. 


\subsection{Granger Casualty Test}

The study continues to use Granger causality test to find out the short term relation among 8 Asian stock markets indices. The most suitable lag is 7 based on AIC series according to test requirement. Results of causality test show that mostly (13) stock market indices are bidirectional, which implies that both markets have short term relationship and can effect each other while 12 market indices are unidirectional which implies that one market have short term relation but the other is free. In the above market indices, 3 pairs of market are totally free from each other cannot cause granger causality. Results are shown in Table 6.

\section{Summery and Conclusion}

This study is carried out among top Asian stock market indices based on market capitalization based on daily price index of last 18 years spanning from January 2000 to December 2017. Data are analyzed in local currency unit obtained from yahoo finance. Problems of missing data due to difference in holidays are fixed by filling the data of adjusted day. Data are transformed into log form for getting absolute changes. Before coinetegration analysis the data are checked through $\mathrm{ADF}$ and PP test at level for stationarity, which confirmed the existence of unit root at level. To make it stationary, data are analyzed at first difference which indicates that all indices are integrated at same order $I(1)$ implying that unit root suggesting the evidence of weak efficiency form of selected Asian markets. Cointegration analysis based on trace statistics shows five cointegrating equation, while the maximum eigen valve test indicates two cointegrating equation at

Table 6. Granger causality test (2000-2017).

\begin{tabular}{|c|c|c|c|}
\hline Hong Kong in China $=>$ Bombay & Unidirectional & Korea $<=>$ Indonesia & Bidirectional \\
\hline Indonesia $<=>$ Bombay & Bidirectional & $\begin{array}{c}\text { Shanghai in China }<=> \\
\text { Indonesia }\end{array}$ & Bidirectional \\
\hline Japan $<=>$ Bombay & Bidirectional & Singapore $=>$ Indonesia & Unidirectional \\
\hline Korea $<=>$ Bombay & Bidirectional & Taiwan in China $<=>$ Indonesia & Bidirectional \\
\hline Shanghai in China $<=>$ Bombay & Bidirectional & Korea $=>$ Japan & Unidirectional \\
\hline Singapore $=>$ Bombay & Unidirectional & Shanghai in China $<=$ Japan & Unidirectional \\
\hline Taiwan in China $<=>$ Bombay & Bidirectional & Singapore = Japan & No causality \\
\hline $\begin{array}{c}\text { Indonesia }<=\text { Hong Kong in } \\
\text { China }\end{array}$ & Unidirectional & Taiwan in China $<=>$ Japan & Bidirectional \\
\hline Japan $=$ Hong Kong in China & No causality & Shanghai in China $=$ Korea & No causality \\
\hline Korean $<=$ Hong Kong in China & Unidirectional & Singapore $<=>$ Korea & Bidirectional \\
\hline $\begin{array}{c}\text { Shanghai in China }<=>\text { Hong } \\
\text { Kong in China }\end{array}$ & Bidirectional & Taiwan in China $<=>$ Korea & Bidirectional \\
\hline $\begin{array}{c}\text { Singapore }=>\text { Hong Kong } \\
\text { in China }\end{array}$ & Unidirectional & $\begin{array}{c}\text { Singapore }<=>\text { Shanghai in } \\
\text { China }\end{array}$ & Bidirectional \\
\hline $\begin{array}{l}\text { Taiwan in China }<= \\
\text { Hong Kong in China }\end{array}$ & Unidirectional & $\begin{array}{c}\text { Taiwan in China }<=\text { Shanghai in } \\
\text { China }\end{array}$ & Unidirectional \\
\hline Japan $=>$ Indonesia & Unidirectional & Taiwan in China $<=$ Singapore & Unidirectional \\
\hline
\end{tabular}

Note: significance at $5 \%$. 
5 percent significant level which implies that these markets are strongly cointegrated in long run which can diversify foreigner investors. The results of granger causality test show 13 pair of markets are bidirectional while 12 pairs are unidirectional and 3 pairs have no causality.

Due to the presence of stationarity, results of unit root suggesting the evidence of weak form of selected Asian market efficiency. It is concluded from the results of Johenson cointegration test that trace statistic shows the evidence of 5 cointegrating vectors while max-eigenvalue shows 2 cointegration vector. These results indicate that all these 8 indices are moving in equilibrium which explores the inefficiency of Asian market. Causality test also shows the indication of short term relation. The result suggest that although there is evidence of cointegration among selected market but still there is scope for efficient portfolio diversification across these markets. For making policy, regional integration play an important role in expanding the base for investors and also broaden the range of financial product, which is helpful for strengthening domestic capital market to compete global market. An integrated markets are useful for decreasing the chances of financial stability and asymmetric shocks, which can strengthen the capability of the economy to absorb the shocks and adequate the risk of international financial contagion.

Further study should be carried out to find the factors that are responsible for the co-movement of these markets together.

\section{Acknowledgements}

This work has been supported by the Humanities and Social Science Planning Project of the Ministry of Education of China (Project, No. 10YJA810017). The Chinese Government scholarship (CSC Council Beijing China), is also greatly acknowledged for providing Financial support (CSC No.2019DFH007448). We also greatly appreciate the thoughtful comments and valuable suggestions from anonymous reviewers for the improvement of this manuscript.

\section{Conflicts of Interest}

The authors declare no conflicts of interest regarding the publication of this paper.

\section{References}

Ahlgren, N., \& Antell, J. (2002). Testing for Cointegration between International Stock Prices. Applied Financial Economics, 12, 851-861. https://doi.org/10.1080/09603100110050743

Ali, S., Butt, B. Z., \& Rehman, K. U. (2011). Comovement between Emerging and Developed Stock Markets: An Investigation through Cointegration Analysis. World Applied Sciences Journal, 12, 395-403.

Beine, M., Cosma, A., \& Vermeulen, R. (2010). The Dark Side of Global Integration: Increasing Tail Dependence. Journal of Banking \& Finance, 34, 184-192.

https://doi.org/10.1016/j.jbankfin.2009.07.014 
Benzion, U., Choi, J., \& Hasuer, S. (1996). The Price Linkages between Country Funds and National Stock Markets: Evidence from Cointegration and Causality Tests of German, Japan and UK Funds. Journal of Business Finance and Accounting, 23, 1005-1017. https://doi.org/10.1111/j.1468-5957.1996.tb01037.x

Chen, G. M., Firth, M., \& Rui, O. M. (2002). Stock Market Linkages: Evidence from Latin America. Journal of Banking \& Finance, 26, 1113-1141. https://doi.org/10.1016/S0378-4266(01)00160-1

Choudhry, T. (1997). Stochastic Trends in Stock Prices: Evidence from Latin American Markets. Journal of Macroeconomics, 19, 285-304. https://doi.org/10.1016/S0164-0704(97)00016-5

Corhay, A., Tourani, A. R., \& Urbain, J. P. (1993). Common Stochastic Trends in European Stock Markets. Economics Letters, 42, 385-390. https://doi.org/10.1016/0165-1765(93)90090-Y

Daly, K. J. (2003). Southeast Asian Stock Market Linkages: Evidence from Pre and Post October 1997. ASEAN Economic Bulletin, 20, 73-84. https://doi.org/10.1355/AE20-1F

Dickey, D. A., \& Fuller, W. A. (1979). Distribution of the Estimators for Autoregressive Time Series with a Unit Root. Journal of the American Statistical Association, 74, 427-431. https://doi.org/10.1080/01621459.1979.10482531

Dickey, D. A., \& Fuller, W. A. (1981). Likelihood Ratio Statistics for Autoregressive Time Series with a Unit Root. Econometrica, 49, 1057-1072. https://doi.org/10.2307/1912517

Dimitrova, D. (2005). The Relationship between Exchange Rates and Stock Prices: Studies in Multivariate Model. Issue in Political Economy, 14, 1-25.

Engle, R. F., \& Granger, C. W. J. (1987). Co-Integration and Error Correction: Representation, Estimation, and Testing. Econometrica, 55, 251-276.

https://doi.org/10.2307/1913236

Fan, W. (2003). An Empirical Study of Cointegration and Causality in the Asia-Pacific Stock Markets. Working Paper, New Haven, CT: Yale University. https://doi.org/10.2139/ssrn.360160

Granger, C. W. (1981). Some Properties of Time Series Data and Their Use in Econometric Model Specification. Journal of Econometrics, 16, 121-130. https://doi.org/10.1016/0304-4076(81)90079-8

Hirayama, K., \& Tsutsui, Y. (1998). Threshold Effect in International Linkage of Stock Prices. Japan and the World Economy, 10, 441-453. https://doi.org/10.1016/S0922-1425(98)00021-8

Johansen, S. (1988). Statistical Analysis of Cointegration Vectors. Journal of Economic Dynamics and Control, 12, 231-254. https://doi.org/10.1016/0165-1889(88)90041-3

Johansen, S., \& Julius, K. (1990). Maximum Likelihood Estimation and Inference on Cointegration-With Applications to the Demand for Money. Oxford Bulletin of Economics and Statistics, 52, 169-210. https://doi.org/10.1111/j.1468-0084.1990.mp52002003.x

Kanas, A. (1998). Linkages between the US and European Equity Markets: Further Evidence from Cointegration Tests. Applied Financial Economics, 8, 607-614. https://doi.org/10.1080/096031098332646

Kasa, K. (1992). Common Stochastic Trends in International Stock Markets. Journal of Monetary Economics, 29, 95-124. https://doi.org/10.1016/0304-3932(92)90025-W

MacKinnon, J. G., Haug, A. A., \& Michelis, L. (1999). Numerical Distribution Functions of Likelihood Ratio Tests Forcointegration. Journal of Applied Econometrics, 14, 563-577. 
Majid, M. S., Meera, K. A., \& Omar, M. A. (2008). Interdependence of ASEAN-5 Stock Markets from the US and Japan. Global Economic Review, 37, 201-225. https://doi.org/10.1080/12265080802021201

Mcmiken, E. D. P. (2014). An Examination of Asian Stock Market: A Cointegration Approach. ASEAN Economic Bulletin, 13, 299-311.

Narayan, P. K., Mishra, S., \& Narayan, S. (2011). Do Market Capitalization and Stocks Traded Converge? New Global Evidence. Journal of Banking \& Finance, 35, 2771-2781. https://doi.org/10.1016/j.jbankfin.2011.03.010

Narayan, P. K., Narayan, S., Popp, S., \& Ali Ahmed, H. (2015). Is the Efficient Market Hypothesis Day-of-the-Week Dependent? Evidence from the Banking Sector. Applied Economics, 47, 2359-2378.

Nasrullah, M., Chang, L., Khan, K., Rizwanullah, M., Zulfiqar, F., \& Ishfaq, M. (2020). Determinants of Forest Product Group Trade by Gravity Model Approach: A Case Study of China. Forest Policy and Economics, 113, Article ID: 102117. https://doi.org/10.1016/j.forpol.2020.102117

Nasrullah, M., Chang, L., Saddozai, K. N., Khalid, A. O., Bayisenge, R., \& Hameed, G. (2019). Cost and Net Return of Tobacco Growers-A Case Study of District Mardan (KP-Pakistan). Sarhad Journal of Agriculture, 35, 565-571. https://doi.org/10.17582/journal.sja/2019/35.2.565.571

Pretorious, E. (2002). Economic Determinants of Emerging Stock Market Interdependence. Emerging Markets Review, 3, 84-105. https://doi.org/10.1016/S1566-0141(01)00032-2

Ragunathan, V. (1999). Financial Deregulation and Integration: An Australian Perspective. Journal of Economics and Business, 51, 505-514. https://doi.org/10.1016/S0148-6195(99)00018-1

Richards, A. J. (1995). Comovements in National Stock Market Returns: Evidence of Predictability, But Not Cointegration. Journal of Monetary Economics, 36, 631-654. https://doi.org/10.1016/0304-3932(95)01225-7

Saddozai, K. N., Nasrullah, M., \& Khan, N. P. (2015). Stochastic Frontier Production Analysis of Tobacco Growers in District Mardan, Pakistan. Pakistan Journal of Agricultural Sciences, 28, 346-353.

Sheng, H.-C., \& Tu, A. H. (2000). A Study of Cointegration and Variance Decomposition among National Equity Indices before and during the Period of the Asian Financial Crisis. Journal of Multinational Financial Management, 10, 345-365. https://doi.org/10.1016/S1042-444X(00)00034-7

Stock, J. H. (1987). Asymptotic Properties of Least Squares Estimators of Cointegrating Vectors. Econometrica, 55, 1035-1056. https://doi.org/10.2307/1911260

Throop, A. W. (1994). International Financial Market Integration and Linkages of National Interest Rates. Economic Review-Federal Reserve Bank of San Francisco, 3, 3-18.

Umutlu, M., Akdeniz, L., \& Altay-Salih, A. (2010). The Degree of Financial Liberalization and Aggregated Stock-Return Volatility in Emerging Markets. Journal of Banking \& Finance, 34, 509-521. https://doi.org/10.1016/j.jbankfin.2009.08.010

Wong, W. K., Agarwal, A., \& Du, J. (2005). Financial Integration for India Stock Market, a Fractional Cointegration Approach. National University of Singapore Working Paper No. 0501.

Wuthisatian, R. (2014). Cointegration of Stock Markets: A Case of Thailand. Review of Market Integration, 6, 297-320. https://doi.org/10.1177/0974929215582244 